\title{
The application of the germination index in the assessment of the phytotoxicity of bottom sediments from the Rybnik Reservoir
}

\author{
Magdalena Szara ${ }^{1}$, Agnieszka Baran ${ }^{1}$, Marek Tarnawski², Tomasz Koniarz $^{2}$ \\ ${ }^{1}$ University of Agriculture in Krakow, Faculty of Agriculture and Economics, \\ Department of Agricultural and Environmental Chemistry; al. A. Mickiewicza 21, 31-120 Krakow, Poland; \\ e-mail: Agnieszka.Baran@ur.krakow.pl,magdalena.szara@student.ukr.edu.pl \\ ${ }^{2}$ University of Agriculture in Krakow, Faculty of Environmental Engineering and Land Surveying, \\ Department of Hydraulic Engineering and Geotechnics; al. A. Mickiewicza 24/28, 30-059 Krakow, Poland; \\ e-mail: marek.tarnawski@ur.krakow.pl
}

(C) 2017 Authors. This is an open access publication, which can be used, distributed and reproduced in any medium according to the Creative Commons CC-BY 4.0 License requiring that the original work has been properly cited.

Received: 11 December 2017; accepted: 02 January 2018

\begin{abstract}
The aims of the study were to assess the phytoxicity of bottom sediments collected from the Rybnik Reservoir. The water reservoir in Rybnik is located in the Silesian Voivodeship. The reservoir constitutes a part of the technological chain of Elektrownia Rybnik S.A. as a direct receiver of industrial and rainwater sewage, sewage from a water treatment plant, blowdowns from cooling towers, and as an essential source of cooling water. Sediment samples were collected with an Eckman sampler from 33 locations. The toxicity of bottom sediments was determined using the Phytotoxkit direct contact test, carried out for 3 plants: Sorghum saccharatum, Sinapis alba and Lepidium sativum. On the basis of the data received, the germination index (GI) was calculated. We found the mean value of the germination index indicated the dominance of the inhibitory effect of bottom sediments on plant growth. Sorghum saccharatum was the most sensitive to pollutants in sediments, while Lepidium sativum was the least sensitive. The Phytotoxkit is a good tool for assessing the toxicity of bottom sediments.
\end{abstract}

Keywords: bottom sediment, phytotoxicity, germination index, Phytotoxkit

\section{INTRODUCTION}

In urban areas, the composition of bottom sediments depends on natural factors (the type of foundations that build the catchment, land geomorphology, climatic conditions) and, to a large extent, anthropogenic factors (the method of the management and use of the catchment, the type and amount of pollutants introduced) (Tarnawski \& Michalec 2006, Aleksander-Kwaterczak 2007, Szalińska 2011, Szarek-Gwiazda 2013). The most common forms of anthropopressure include industrial and municipal sewage discharges to waters as well as dust and gas pollution in the atmosphere (Kostecki 2004, Dmitruk et al. 2013, Ciszewski et al. 2013, Baran \& Tarnawski 2015). The migration of pollutants in the aquatic environment occurs under the influence of transport and sedimentation processes (Jasiewicz \& Baran 2006, Jancewicz et al. 2012). The structure of sediments makes them a natural geosorbent, i.e. a place where the accumulation of migrating pollutants takes place (Förstner \& Salomons 2010, Szarek-Gwiazda 2013, Baran \& Tarnawski 2013, 2015). Currently, according to numerous studies, classic chemical methods do not provide sufficient information on the potential hazard resulting from the presence of pollutants in bottom 
sediments, for which biotests are a useful tool, the use of which allows a comprehensive assessment of bioavailability, toxicity and interoperability (Latif \& Licek 2004, Mankiewicz-Boczek et al. 2008, Mamindy-Pajany et al 2011, Baran \& Tarnawski 2013). A biological response of a test organism is measured as the result of the combined effect, including antagonism and synergism, of the mixture of all potential pollutants contained in the sediment (Wadhia \& Thompson 2007, Wolska et al. 2007, Lopez-Rondan et al. 2012). The necessity to analyse a large number of environmental samples induced the popularisation of miniaturised toxicity tests - microbiotests, which are easy to carry out, characterised by their simplicity of observation, repeatability of results, and the fact that they do not require expensive laboratory equipment (Smreczak \& Maliszewska-Kordybach 2003, Wolska et al. 2007, Oleszczuk 2008). The Phytotoxkit is a root biotest for chronic toxicity testing. It is based on three plants: monocotyledonous Sorghum saccharatum as well as dicotyledonous Sinapis alba and Lepidium sativum, whose germinating seeds, as a result of contact with substances contained in sediments, show specific reactions: a lack of germination or a reduction of root length. Inhibition of reactions or vital functions of the test organisms indicates the presence of harmful factors or units in the environmental matrices (Wadhia \& Thompson 2007, Łaszczyca et al. 2012). Moreover, it is worth noting that plants are important components of ecosystems; they are the primary food producers and, therefore, it is important to identify the magnitude of the toxic effects on these organisms (Czerniawska-Kusza et al. 2006, Garcia-Lorenzo et al. 2009, Czerniawska-Kusza \& Kusza 2011, Baran \& Tarnawski 2013).

The aims of the study were to assess the phytoxicity of bottom sediments collected from the Rybnik Reservoir (Silesian area) and to evaluate the spatial distribution sediment toxicity using the Phytotoxkit microbiotest.

\section{MATERIALS AND METHODS}

\section{Study area}

The water reservoir in Rybnik is located in the Rybnik Coal Basin in the Silesian Voivodeship (Fig. 1). It was formed in 1972 as a result of the damming of the Ruda River, a right-bank tributary of the Oder. The total capacity of the reservoir amounts to $24 \mathrm{mln} \mathrm{m}^{3}$, while its average depth is $5.4 \mathrm{~m}$ (Tab. 1) (Wiechuła et al. 2005).

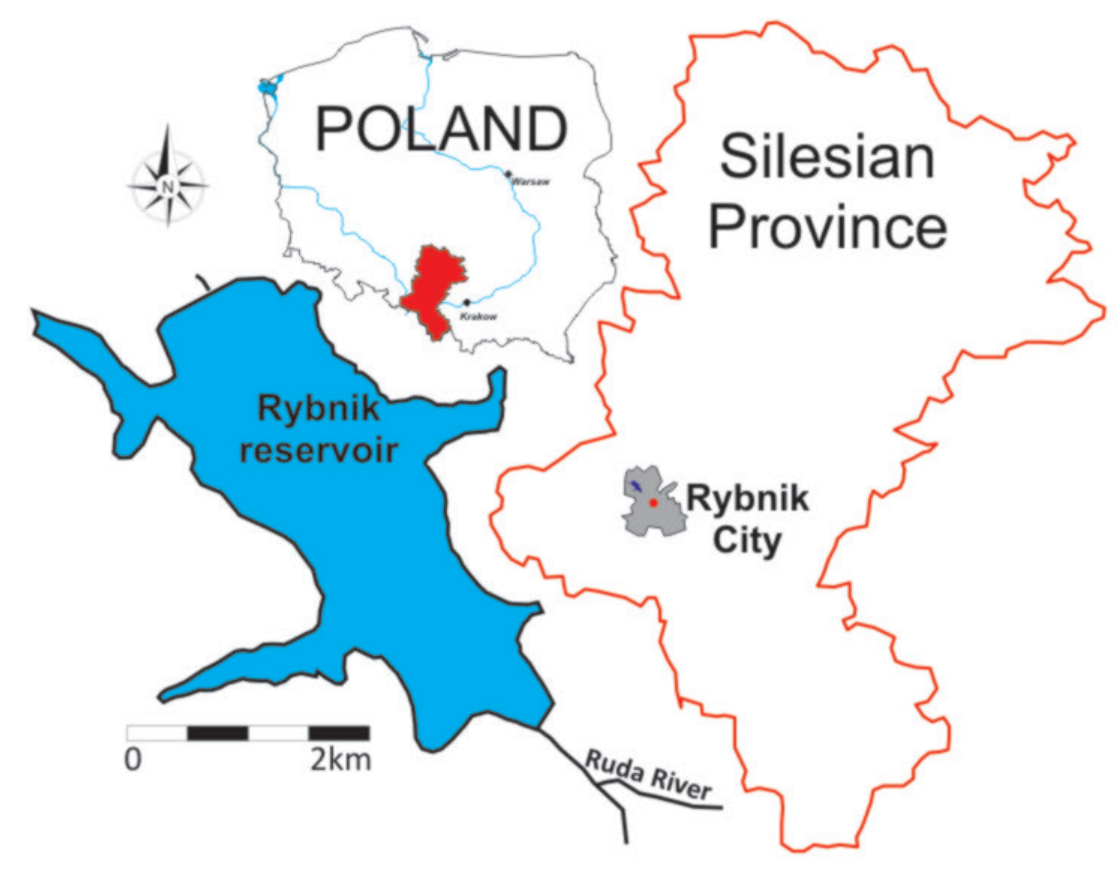

Fig. 1. Localization of the Rybnik Reservoir 
Table 1

Characteristic parameters of the Rybnik Reservoir

\begin{tabular}{|l|l|}
\hline \multicolumn{1}{|c|}{ Parameter } & \multicolumn{1}{c|}{ Value } \\
\hline Storage reservoir $\left[\mathrm{mln} \mathrm{m}^{3}\right]:$ & \\
total & 24 \\
flood storage & 1.5 \\
usable storage & 4.3 \\
dead storage & 18.2 \\
\hline Lenght of reservoir $[\mathrm{km}]$ & 4.5 \\
\hline Area of the reservoir $[\mathrm{ha}]$ & 555 \\
main reservoir & 444 \\
\hline The dam earth embankment $[\mathrm{m}]$ & \\
lenght & 975.00 \\
maximum height & 12.00 \\
\hline Outlet facilities: & $2 \times 5.0 \mathrm{~m}$ \\
spillway & max. outflow $60 \mathrm{~m}^{3} \cdot \mathrm{s}^{-1}$ \\
& $3 \times 1.8 \times 1.8 \mathrm{~m}$ \\
bottom river outlet & max. outflow $39 \mathrm{~m}^{3} \cdot \mathrm{s}^{-1}$ \\
\hline
\end{tabular}

The area around the reservoir is characterised by great diversity, from recreational development with dispersed urban development, through numerous industrial and commercial areas, dumping grounds and heaps, up to a small number of areas used for agriculture and forestry. The reservoir constitutes a part of the technological chain of Elektrownia Rybnik S.A. as a direct receiver of industrial and rainwater sewage, sewage from a water treatment plant, blowdowns from cooling towers, and as an essential source of cooling water (Baran \& Tarnawski 2015, Baran et al. 2016). There is a strong emission of dust and gas pollution in the Silesian Voivodeship, accounting for 19\% of the total emissions in Poland. The highest point sources of atmospheric air pollution are CHP plants (EC Nowa - Dąbrowa Górnicza, Chorzów ELCHO, Będzin), power plants (Rybnik, Jaworzno III, Łagisza, Łaziska, Halemba), Częstochowa steelworks, coke-oven plants (Przyjaźń Dąbrowa Górnicza) and the Arcelor Mittal plant in Dąbrowa Górnicza. Pollutants transported in the atmosphere and introduced with wet atmospheric precipitation constitute a significant source of pollution in the area (Jancewicz et al. 2012). According to atmospheric chemistry studies from the IMGW-PIB station in Katowice (Muchowiec) and Racibórz, "acid rain", i.e. precipitation below $\mathrm{pH} 5.6$ indicating the natural acidity level of rainwater, showing the content of strong mineral acids, was reported in the case of $35 \%$ of samples in 2015. Sulphates, chlorides, ammonium nitrogen, general nitrogen, calcium and chlorine were found at the highest concentrations. The analysis of the content of pollutants accumulated in the bottom sediments of reservoirs located in the Silesian Voivodeship showed high levels of trace elements and persistent organic pollutants (Stan środowiska, 2016).

\section{Sample collection}

Sediment samples were collected in July - August 2017 with an Eckman sampler from 33 set locations. Based on our previous studies, three zones were determined in the reservoir (Baran et al. 2016). The sediment samples were collected from inlet (backwater), middle and outlet (near to dam) zone. In each zone, 12, 10 and 11 samples of the upper layer of bottom sediments $(0-15 \mathrm{~cm})$ were collected respectively. The sediments were put in polyethylene containers and transported to the laboratory. The sediment samples were refrigerated in darkness until analysed.

\section{Phytotoxkit biotest}

The toxicity of bottom sediments was determined using the Phy totoxkit direct contact test, carried out in accordance with the ISO procedure and standard (Phytotoxkit, 2004, ISO 18763:2016). The test was carried out for 3 plants: Sorghum saccharatum (monocotyledonous), Sinapis alba and Lepidium sativum (dicotyledonous). The sediment samples were placed in the bottom part of $21 \mathrm{~cm} \times 15.5 \mathrm{~cm} \times$ $0.8 \mathrm{~cm}$ test plates and covered with a paper filter. At a distance of approx. $1 \mathrm{~cm}$ from the top edge of the filter, 10 seeds of the same plant species were placed. The plates were closed with covers and incubated in a vertical position at $25^{\circ} \mathrm{C}$ in the dark for 72 hours. After this time, pictures were taken and then, using the Image J image analysis programme, the number of seeds germinated was determined and the root length was measured. On the basis of the data received, the germination index (GI) was calculated according to the following formula:

$\mathrm{GI}=\frac{\mathrm{GsLs}}{\mathrm{GcLc}} \times 100 \%$

where Gs and Ls are the seed germination [\%] and root elongation $[\mathrm{mm}]$ for the sample, and Gc and Lc are the corresponding control values. GI values 
within the range of $90-110 \%$ were classified as "no effect/non-toxic", GI values $<90 \%$ were classified as inhibition, and GI values $>110 \%$ were classified as stimulation (Beltrami et al. 1999, Czerniawska-Kusza \& Kusza 2011, Baran \& Tarnawski 2013).

\section{Statistical analysis}

The results were expressed as mean \pm standard deviation (SD), minimum and maximum values and coefficient of variation (CV\%). Pearson's correlation matrix was used to explore the possible relationships between plants. The differences between the means were detected by ANOVA and Tukey's test to be at a significance level of 0.05 . All statistical analyses were preformed using Microsoft Office Excel and STATISTICA 12.0 software.

\section{RESULTS AND DISCUSSION}

Table 2 presents the germination index of three plant species exposed to the tested sediment. The value of the germination index was in the range from 22 to 117\% for Sinapis alba, from 32 to 158\% for Lepidium sativum, and from 6 to $110 \%$ for Sorghum saccharatum. In general, the mean and low spatial variability of bottom sediment toxicity, indicated with GI, was exhibited. This parameter indicated the highest spatial differentiation for $S$. saccharatum $(\mathrm{CV}=55 \%)$ and the lowest for S. alba (CV = 28\%) (Tab. 2, Fig. 2). For each of the plants, the mean value of the germination index indicated the dominance of the inhibitory effect of the tested sediment on plant growth.

Table 2

Germination index values (GI) for sediment samples

\begin{tabular}{|l|c|c|c|c|c|c|}
\hline \multicolumn{1}{|c|}{ Plants } & Mean & Median & SD & Minimum & Maximum & CV\% $^{*}$ \\
\hline Sinapis alba & $79 \mathrm{~b}^{* *}$ & 80 & 21 & 22 & 117 & 26 \\
\hline Lepidium sativum & $84 \mathrm{~b}$ & 84 & 32 & 32 & 158 & 38 \\
\hline Sorghum saccharatum & $57 \mathrm{a}$ & 67 & 31 & 6 & 110 & 55 \\
\hline
\end{tabular}

${ }^{*} \mathrm{CV} \%$ - variation coefficient.

** Means followed by the different letters in line indicate significant differences at $\alpha \leq 0.05$ according to the t-Tukey test.

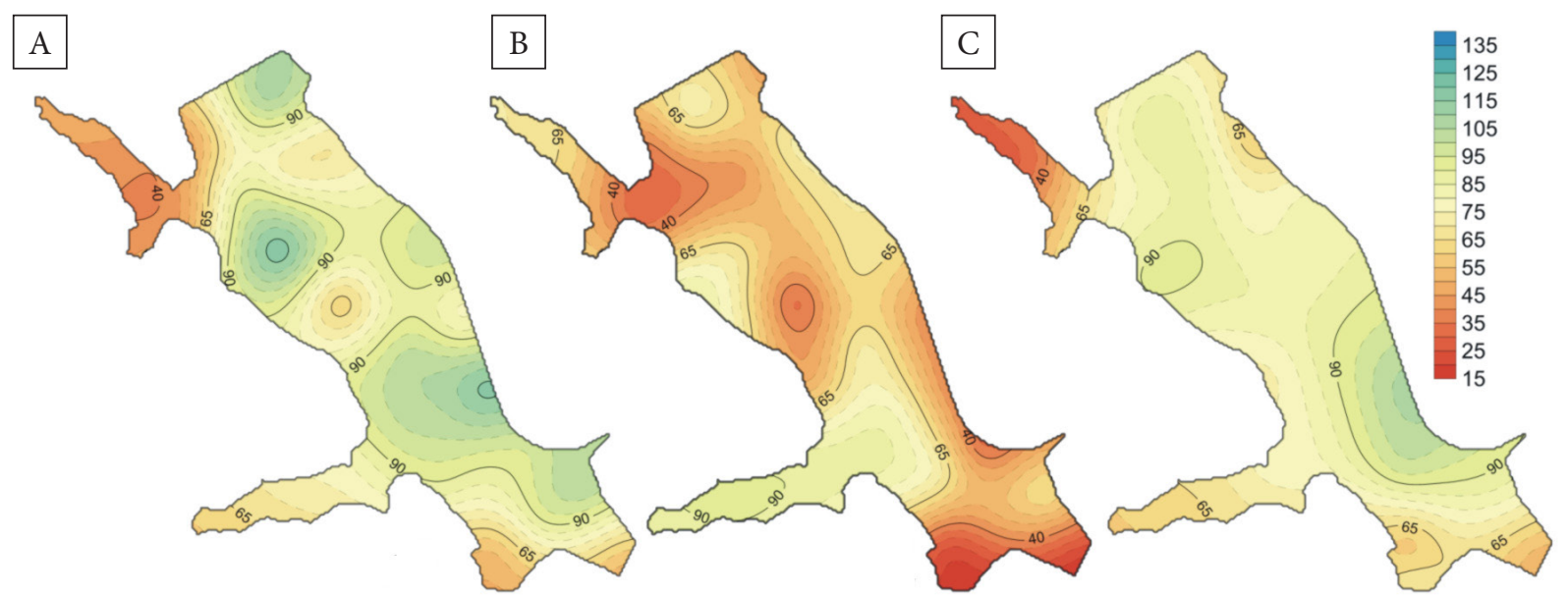

Fig. 2. Spatial distribution phytotoxicity (GI) of bottom sediments: A) Lepidium sativum; B) Sorghum saccharatum; C) Sinapis alba 
The monocotyledonous plant $S$. saccharatum was indeed the most sensitive to pollutants present in the sediments. The calculated germination index for S. saccharatum indicated that as much as $85 \%$ of the sediment samples inhibited the growth of this plant (GI < 90\%), while $15 \%$ of the samples showed no stimulation or inhibition. This result is in agreement with the works by Czerniawska-Kusza et al. (2006), Czerniawska-Kusza \& Kusza (2011), Mamindy-Pajany et al. (2011), Baran \& Tarnawski (2015) who reported that S. saccharatum is the most sensitive species for identifying phytotoxic sediment samples compared to L. sativum and S. alba. Among dicotyledonous plants, $S$. alba turned out to be a more sensitive one since up to $73 \%$ of the sediment samples were observed to inhibit its growth. Neither positive nor negative reactions of $S$. alba were found in $24 \%$ of the sediment samples, while stimulation of plant growth was observed in 3\% of the samples. L. sativum was the least sensitive to the bottom sediment from the Rybnik reservoir. Inhibition of plant growth was observed in 52\% of the sediment samples, whereas stimulation was reported in $15 \%$ of the samples. In the study, a significant correlation between the growth inhibition of L. sativum and the growth inhibition of $S$. alba and $S$. saccharatum $(r=0.36, r=0.43$, $p<0.5)$ was found, so it would seem that the correlation analysis showed a similar sensitivity to toxicants in the sediments. However, the observed relationship between the response of the test organisms was statistically insignificant, as it explained only $13 \%$ and $18 \%$ of variations, respectively.

Figure 3 presents the values of the germination index of plants depending on the characteristic zone in the reservoir. Three main zones were selected: inlet (backwater zone, I), middle (II), outlet (dam, III). It is interesting that GI values grouped in such a way indicated the inhibitory effect of sediments on the growth of the test plants. Regardless of the plant tested, the sediment samples collected in the inlet zone (I) and then in the outlet zone (dam, III) were characterised by the highest toxicity. The sediment samples from the middle (II) part of the reservoir showed the least negative impact on plant growth.

Our previous studies found that the most polluted sediments are found at points in the inlet zone and near the dam (outlet zones) and close to dam (Baran et al. 2016). The pollution of sediments by metals and PAHs is associated with the discharge of cooling water from the power plant and with an inflow of contaminated water of the Ruda River and long-range transport.

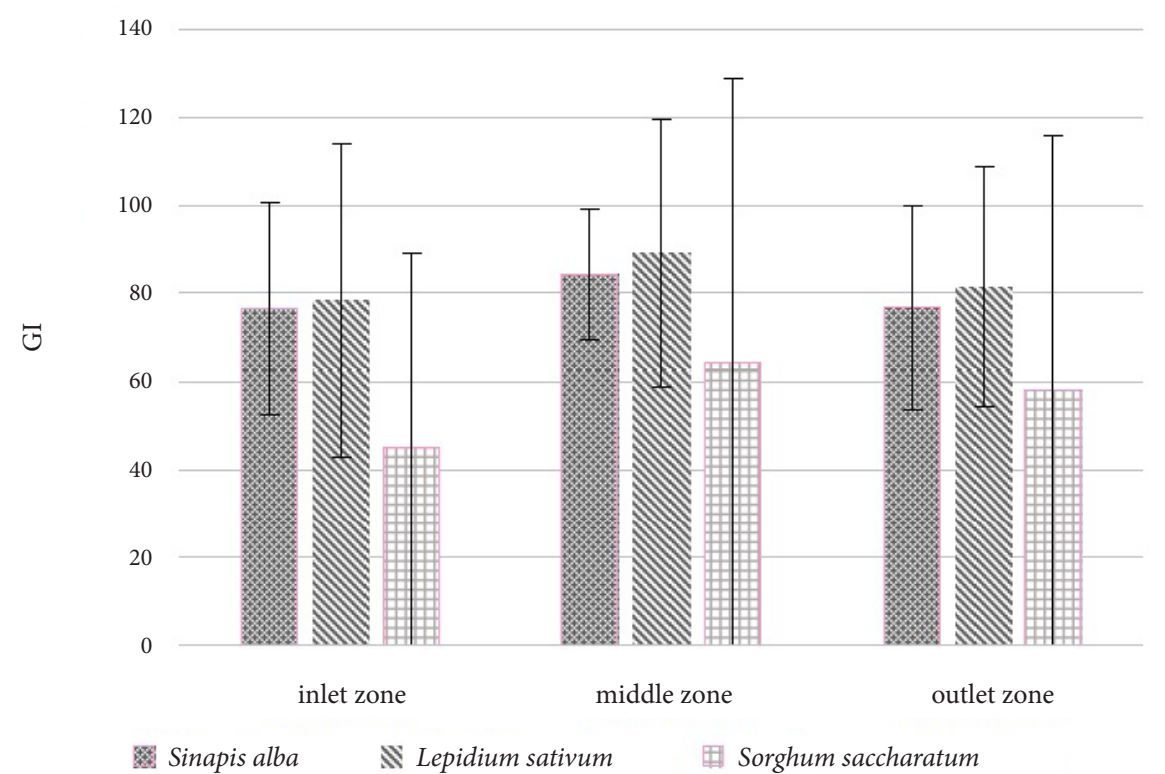

Fig. 3. Germination index of plants depending on the zone in the reservoir 
Specific currents are formed in the reservoir as a result of discharge water from a power plant. These currents cause the formation of the discharge area, a zone of significantly increased levels of metals in sediments (Kostecki 2004, Kostecki \& Kowalski 2004). Other sources of sediment contamination include: treated industrial sewage emitted by the Rybnik power plant, municipal sewage, rain wastewaters, sewage from the water treatment plant, cooling tower blowdowns, and dry precipitation (Loska \&Wiechuła 2003, Baran et al. 2017).

The toxicity of the analysed sediments against test plants can be also caused by numerous chemical factors. Many authors point to heavy metals contained in sediments as a basic factor inhibiting the growth of test plants (Valerio et al. 2007, Czerniawska-Kusza \& Kusza 2011). In the studies conducted by Kostecki \& Kowalski (2004) and Baran et al. (2016), it was shown that the bottom sediments of the Rybnik Reservoir are polluted with heavy metals. However, Potential Ecological Risk Index (PERI) values suggested that $70 \%$ of the samples exhibited a low ecological risk from metal pollution, while $24 \%$ of the samples had severe or serious risk. Low or no toxicity of sediments from heavy metals may be caused i.a. by their presence in a very stable and insoluble form, a high content of organic matter or clay fraction as well as a neutral or a slightly alkaline reaction (Baran \& Tarnawski $2013,2015)$. The studies conducted by Gong et al. (2001) and Czerniawska-Kusza et al. (2006) also confirmed that the false assessment may be caused by sediments rich in organic matter, which can hide the inhibitory effect of pollutants on test plants. The lack of significant dependencies between the content of metals in the sediments and the response of test organisms also suggest that other factors, such as arsenic, PAHs, PCBs and dioxins, may be present in the sediments, determining their toxicity (Urbaniak et al. 2013, Baran et al. 2017). In the study of Baran et al. (2017), it was found that individual PAHs, such a NAP, PHE, FLT, PYR, BAA, CHR, BAP, in sediments from the Rybnik Reservoir indicated a higher possibility of the occurrence of an adverse ecological effect. In addition, the specific interactions occurring between pollutants may also result in antagonistic or synergistic effects, the prediction of which may be challenging (Kabata-Pendias \& Pendias 1999, Baran \& Tarnawski
2015, Czarniewska-Kusza et al. 2006, Simeonov et al. 2007).

\section{CONCLUSIONS}

1. The tested monocotyledonous (S. saccharatum) and dicotyledonous plants (S. alba and L. sativum) reacted differently, reflecting their own physiological mechanisms of reaction to stress factors. However, for each of the plants, the mean value of the germination index indicated the dominance of the inhibitory effect of bottom sediments on their growth.

2. Sorghum saccharatum was the most sensitive to pollutants in sediments, while Lepidium sativum was the least sensitive.

3. Sediments in the inlet zone of the reservoir showed the highest toxicity level for the test plants.

4. Phytotoxkit is a good tool for assessing the toxicity of bottom sediments. However, for this assessment to be comprehensive and reliable, it is necessary to use biotest batteries consisting of organisms belonging to different species and trophic levels.

The study was financed by grant no. 2016/21/B/ ST10/02127 "Assessment of the bottom sediment organic matter on bioavailability and toxicity of chemical compounds" provided by the National Science Centre, Poland.

\section{REFERENCES}

Aleksander-Kwaterczak U., 2007. Rozmieszczenie metali śladowych $w$ rdzeniach osadów wybranych rzek Polski. Uczelniane Wydawnictwa Naukowo-Dydaktyczne AGH, Kraków.

Baran A. \&Tarnawski M., 2013. Phytotoxkit/Phytotestkit and Microtox $^{\oplus}$ as tools for toxicity assessment of sediments. Ecotoxicology and Environmental Safety, 98, 19-27.

Baran A. \& Tarnawski M., 2015. Assessment of heavy metals mobility and toxicity in contaminated sediments by sequential extraction and a battery of bioassays. Ecotoxicology, 24, 6, 1279-1293.

Baran A., Tarnawski M. \& Koniarz T., 2016. Spatial distribution of trace elements and ecotoxicity of bottom sediments in Rybnik reservoir, Silesian-Poland. Environmental Science and Pollution Research, 23, 17, 17255-17268.

Baran A., Tarnawski M., Urbański K., Klimkowicz-Pawlas A. \& Spałek I., 2017. Concentration, sources and risk assessment of PAHs in bottom sediments. Environmental Science and Pollution Research, 24, 29, 23180-23195. 
Beltrami M., Rossi D. \& Baudo R., 1999. Phytotoxicity assessment of lake Orta sediments. Aquatic Ecosystem Health, 2, 391-401.

Ciszewski D., Aleksander-Kwaterczak U., Pociecha A., Szarek-Gwiazda E., Waloszek A. \& Wilk-Woźniak E., 2013. Small effects of a large sediment contamination with heavy metals on aquatic organisms in the vicinity of an abandoned lead and zinc mine. Environmental Monitoring and Assessment, 185, 12, 9825-9842.

Czerniawska-Kusza I. \& Kusza G., 2011. The potential of the Phytotoxkit microbiotest for hazard evaluation of sediments in eutrophic freshwater ecosystems. Environmental Monitoring and Assessment, 179, 113-121.

Czerniawska-Kusza I., Ciesielczuk T., Kusza G. \& Cichon A., 2006. Comparison of the Phytotoxkit microbiotest and chemical variables for toxicity evaluation of sediments. Environmental Toxicology, 378, 367-372.

Dmitruk U., Jancewicz A. \& Tomczuk U., 2013. Hazardous organic and trace element occurrence in bottom sediments of dam reservoirs. Environmental Pollution Control, 35, 2, 63-68.

Förstner U. \& Salomons W., 2010. Sediment research, management and police. Journal of Soils and Sediments, 10, $1440-1452$.

Garcia-Lorenzo M.L., Martinez-Sanchez M.J., Perez-Sirvent C. \& Molina J., 2009. Ecotoxicological evaluation for the screening of areas polluted by mining activities. Ecotoxicology, 18, 1077-1086.

Gong P., Wilke BM., Strozzi E. \& Fleischmann S., 2001. Evaluation and refinement of a continuous seed germination and early seedling comparison of the Phytotoxkit microbiotest and chemical variables. Environmental Toxicology. Chemosphere, 44, 491-500.

ISO 18763:2016: Soil quality - Determination of the toxic effects of pollutants on germination and early growth of higher plants.

Jancewicz A., Dmitruk U., Sośnicki Ł., Tomczuk U. \& Bartczak A., 2012. Influence of land development in the drainage area on bottom sediment quality in some dam reservoirs. Environmental Pollution Control, 34, 29-34.

Jasiewicz Cz. \& Baran A., 2006. Characteristics of bottom sediments of two reservoirs of small water retention. Journal of Elementology, 11, 3, 307-317.

Kabata-Pendias A. \& Pendias H., 1999. Biogeochemia pierwiastków śladowych. Wydawnictwo Naukowe PWN, Warszawa.

Kostecki M. \& Kowalski E., 2004. Alokacja metali ciężkich w osadach dennych zbiornika rybnickiego. Archiwum Ochrony Środowiska, 30, 4, 53-62.

Kostecki M., 2004. Wpływ antropopresji na kształtowanie się układów termicznych w Rybnickim Zbiorniku zaporowym. Archiwum Ochrony Srodowiska, 30, 4, 41-52.

Łaszczyca P., Francikowski J., Guzik J., Nikiel A., Kłosok M., Michalczyk K., Augustyniak M. \& Migula P., 2012. Przydatność biotestów ekotoksykologicznych do oceny stanu biologicznego wód na przykładzie zbiornika zaporowego w goczałkowicach. Kosmos, 61, 3, 381-392.

Latif M. \& Licek E., 2004. Toxicity assessment of wastewaters, river water and sediments in Austria using cost-effective microbiotests. Environmental Toxicology, 19, 4, 302-309.

Lopez-Roldan R., Kazlauskaite L., Ribo J., Riva M.C., Gonzalez S. \& Cortina J.L., 2012. Evaluation of an automated luminescent bacteria assay for in situ aquatic toxicity determination. Science of the Total Environment, 440, 307-313.

Mamindy-Pajany Y., Hamer B., Roméo M., Géret F., Galgani F., Durmisi E., Hurel C. \& Marmier N., 2011. The toxicity of composted sediments from Mediterranean ports evaluated by several bioassays. Chemosphere, 83, 3, 362-369.

Mankiewicz-Boczek J., Nałęcz-Jawecki G., Drobniewska A., Kaza M., Sumorok B., Izydorczyk K., Zalewski M. \& Sawicki J., 2008. Application of microbiotest battery for complete toxicity assessment of rivers. Ecotoxicology and Environmental Safety, 71, 830-836.

Oleszczuk P., 2008. The toxicity of composts from sewage sludges evaluated by the directcontact tests Phytotoxkit and Ostracodtoxkit. Waste Management, 28, 1645-1653.

Phytotoxkit, 2004. Seed germination and early growth microbiotest with higher plants. Standard Operational Procedure. MicroBioTest Inc, Nazareth, Belgium.

Simeonov V., Wolska L., Kuczyńska A., Gurwin J., Tasakovki S., Protasowicki M. \& Namieśnik J. 2007. Sediement-quality assessment by intelligent data analysis. TrAC Trends in Analytical Chemistry, 26(4), 323-331. DOI: 10.1016/j.trac.2006.12.004.

Smreczak B. \& Maliszewska-Kordybach B., 2003. Seeds germination and root growth of selectedplants in PAH contaminated soil. Fresenius Environmental Bulletin, 12, 946-949.

Stan środowiska 2016. Stan środowiska w województwie ślaskim w roku 2015. Biblioteka Monitoringu Środowiska, Wojewódzki Inspektorat Ochrony Środowiska, Katowice 2016.

Szalińska E., 2011. Rola osadów dennych w ocenie jakości środowiska wód kontynentalnych. Monografia - Politechnika Krakowska im. Tadeusza Kościuszki 396, Wydawnictwo Politechniki Krakowskiej, Kraków.

Szarek-Gwiazda E., 2013. Czynniki ksztattujace stężenia metali ciężkich $w$ rzece Rabie i niektórych karpackich zbiornikach zaporowych. Studia Nature, 60, Instytut Ochrony Przyrody PAN, Kraków.

Tarnawski M. \& Michalec B., 2006. Charakterystyka ilościowa i jakościowa osadów dennych zbiornika wodnego w Wilczej Woli. Infrastruktura i Ekologia Terenów Wiejskich, 3, 1, 31-43.

Urbaniak M., Zieliński M., Kaczkowski Z. \& Zalewski M., 2013. Spatial distribution of PCDDs, PCDFs and dl-PCBs along the cascade of urban reservoirs. Hydrology Research, 44, 4, 614-630.

Valerio M.E., Garcia J.F. \& Peinado F.M., 2007. Determination of phytotoxicity of soluble elements in soils, based on a bioassay with lettuce (Lactuca sativa L.). Science of the Total Environment, 378, 63-66.

Wadhia K. \& Thompson K.C., 2007. Low-cost ecotoxicity testing of environmental samples using microbiotests for potential implementation of the Water Framework Directive. Trends in Analytical Chemistry, 26, 300-307.

Wiechuła I., Loska K. \& Korus I., 2005. Lead partitioning in the bottom sediment of Rybnik reservoir (Southern Poland). Water Air and Soil Pollution, 164, 1, 315-327.

Wolska L., Sagajdakowa A., Kuczyńska A. \& Namieśnik J., 2007. Application of ecotoxicological studies in integrated environmental monitoring: Possibilities and problems. TrAC Trends in Analytical Chemistry, 26, 4, $332-344$. 